\title{
The Economic Valuation and Commensuration of Cultural Resources: Financing and Monitoring the Swedish Culture Sector
}

\author{
Alexander Styhre
}

\begin{abstract}
Economic sociology treats the process of valuation and commensuration of resources as socially-embedded practices determined by historical, cultural, and political conditions. Empirical studies of valuation and commensuration demonstrate that the practices of creating metrics, accounting procedures, and other forms of numerical representations that denote underlying resources are bound up with social interests and instituted beliefs. Recently, cultural resources and culture production have been advocated as key drivers of economic growth in what has been branded the "the creative economy." At the same time, a lot of cultural resources and culture production are, historically, not strictly valued in terms of economic worth, instead being commonly regarded as having an intrinsic social value. Such norms disconnect cultural resources and economic worth, while much culture production is simultaneously being funded by welfare states, making the allocation of public funding a matter of professional expertise. This article reports on a study of how officers of a regional Culture Agency allocate regional culture budgets and monitor culture production via processes of valuation and commensuration. The study contributes to our understanding of how valuation and commensuration play a role in non-market or pseudo-market settings where both political interests and wider social interests are bound up with calculative practices.
\end{abstract}

Key words: economic sociology; valuation; commensuration; culture resources; culture politics; the creative economy

Alexander Styhre, Dept. of Business Administration, School of Business, Economics and Law, University of Gothenburg, Box 601, 40530 Gothenburg, Sweden, e-mail: alexander.styhre@handels.gu.se

(C) 2013 Alexander Styhre

LiU Electronic Press, DOI 10.3384/vs.2001-5992.131151

http://valuationstudies.liu.se 


\section{Introduction}

In order to produce culture, there needs to be a financing of cultural activities. The financing of cultural institutions and cultural production, in the contemporary welfare state, is commonly a matter of allocating the tax revenues in cultural budgets enacted by political bodies. This study demonstrates how the allocation of culture budgets is bound up with professional expertise when valuing and commensurating various cultural activities.

The emerging economic sociology literature on valuation and the economics of worth suggests that terms such as "value" and "market" are not trivial social constructs but the outcome of extensive social practices and institutional work on rendering heterogeneous resources commensurable (Aspers 2009; Beckert 2002; Fligstein 2001; Callon 1998). Here, Carruthers and Babb (1996, 1556), studying the introduction of paper bills-"greenbacks"-during the nineteenth century in the US as a means of lowering the cost of economic transactions, remark that "money works best when it can be taken for granted, when its value, negotiability, and neutrality can simply be assumed." The money economy, as well as a series of other human accomplishments, is thus dependent on common agreement that certain institutions need to be respected in order to function as a collective accomplishment. In other words, the money economy and the circulation of paper money are based on the "naturalization" of such means of payment (Simmel 1978). Such naturalization always presupposes a certain amount of "forgetfulness," loss of the memory of the institutional work underlying the instituting of particular social orders. "Together, naturalization and forgetfulness provide a foundation for institutions," Carruthers and Babb conclude (1996, 1558). Historical studies of processes of valuation; the inscription of economic value, preferably in the form of a metric such as a market price; and commensuration; "the valuation or measuring of different objects with a common metric" (Espeland and Stevens 2008, 408), that is, the comparing of, for example, market prices; show that the naturalization of prices and value is by no means an uncomplicated social process but one that is embedded in institutional settings and professional norms. For instance, in the British and German textile industries, the notion of labour as a commodity only came about following substantial struggles between social actors and the work of articulating economic theories that rendered labor as a commodity among others (Biernacki 1995). In reproductive medicine, human reproductive material such as oöcyte (unfertilized eggs) and sperm is subject to international trade, and the pricing of such material remains contested (Almeling 2007). Also, in the case of the pricing of relatively easily-commodified resources such as electricity, there is historical evidence of competing procedures and policies with regard to how to determine prices (Yakubovich, Granovetter, and McGuire 2005). 
Especially when valuing and pricing what Fourcade (2011) calls "peculiar goods," i.e. goods that do not easily lend themselves to economic valuation and commensuration without violating social norms (see, for example, Zelizer [2005; 1985] on the pricing of "intimacy" and children's lives), the process of valuation and commensuration becomes complicated and riddled by controversy.

Culture production and consumption is one field where "peculiar goods" are priced and paid for. In many welfare states, the culture sector is financed by tax revenues, thus positioning culture production in a pseudo-market where culture goods (in the widest sense of the term, including all sorts of performances and events) generate income through the box-office while being subsidized by the state, region, or municipality. In this view, a qualitative "cultural infrastructure" (including cultural institutions, culture festivals and events, education programs, and other relevant activities) is regarded as a vital part of the welfare state. In addition, over the last decade, culture has been re-enacted by politicians and social commentators as an economic resource that can play a key role in propelling the economy during the coming decades. Terms such as "the creative economy" (e.g., Howkins 2002; Adler 2011) and "aesthetic knowledge" (Ewenstein and Whyte 2007) have been widely endorsed in political and cultural circles alike. Regardless of such new perspectives, the process whereby political decisions regarding the size of culture budgets and the actual allocation of financial resources within the culture sector is a bureaucratic procedure determined by political interests and agendas, professional norms, administrative routines, and legal frameworks. That is, the tax revenues allocated to culture production do not trickle down effortlessly to the producers of culture; instead, the very allocation of financial resources is in itself a professional and administrative procedure that involves professional skills such as the valuation and commensuration of culture production.

This article demonstrates how officers of a regional Culture Agency in Sweden institute routines for the valuation and commensuration of culture production. The study suggests that the professional skill of balancing political interests and an intimate understanding of the actual day-to-day culture production in situ constitute a domain of expertise which, on the one hand, avoids a "politicization" of the culture sector while maintaining, on the other, control of how culture budgets are allocated and translated into activities. In other words, the economic sociology literature by no means solely provides an abstract analytical vocabulary separated from everyday work; concepts such as valuation and commensuration instead denote activities that take place on a daily basis at, for example, the regional Culture Agency as part of the culture politics being put into practice. The study therefore contributes to the literature on valuation and commensuration by demonstrating that culture budgets and production; (1) are co-aligned 
through the use of specific professional and administrative procedures and routines enabling the valuation and commensuration of culture production and, (2) that such "co-alignment" is based on the experience and political-administrative savoir-faire acquired by the culture officers after doing years of practical work.

The remainder of the paper is structured into four sections of which the first outlines the theoretical framework guiding the empirical study, including the key terms valuation and commensuration. Then, the methodology of the study is addressed. Thirdly, the empirical material is reported on and, finally, some theoretical and practical implications raised by the study are discussed.

\section{Valuation and Commensuration as Social Practices}

The economic sociology literature avoids assumptions regarding "human nature" and human dispositions and preferences for forms of rationality, instead treating economic life and economic transactions as being contingent on social, cultural, and historical conditions (Guillén et al. 2002; Bourdieu 2005). That is, rather than adhering to strictly calculative and instrumental rationalities, humans engage in economic activities and transactions on the basis of a variety of concerns and considerations. In the work of allocating financial resources to actors in the culture sector, as examined in this article, officers engage in two principal activities, i.e. the totality of activities defining the value of a certain form of culture production (e.g., performing arts, visuals arts, specific education programs) and the totality of activities aimed at comparing these culture offerings, i.e. the commensuration of alternative forms of culture production. In order to allocate culture budgets, culture officers need to determine the social worth of a specific culture activity, but they also need to decide how to balance various forms of culture production and how to promote professional, "elite" culture production while also fulfilling the political goal of supporting "amateur" or "youth" culture. In the following sections, the analytical terms valuation and commensuration are examined.

\section{Valuation}

While there are many resources and events that have not been translated into economic figures without violating social norms-e.g., the calculation of the worth of human life and economic compensation for injuries occurring in health care (Samuel, Dirsmith, and McElroy 2005), the insurance industry (Ericson, Barry, and Doyle 2000), or during clinical trials in the pharmaceutical industry (Fischer 2009; Petryna 2009)—such work is silently conducted on an everyday basis (Fourcade 2011, 1723). Since monetary terms are used to measure the allocation of resources in late-modern, capitalist society, Fourcade (2011, 1725) writes, "[m]onetary commensuration (or economic valuation) techniques are numerous and varied." She continues: "The 
production, selection, and application of these techniques is thus extraordinarily contingent and deeply political, raising questions about 'scientific trials of strength' and the processes of 'translation' and 'allies of enrollment' (Latour 1987) that stand behind them." While, for instance, accounting techniques and procedures are taking on an air of "objectivity" and "procedural transparency" (Robson 1992), they too are the outcome of historically-contingent processes whereby merchants needed to establish themselves as credible and trustworthy economic agents (Carruthers and Espeland 1991; Poovey 1991). Similar to Beckert (2009), Fourcade emphasizes the fact that economic valuation and commensuration are "social processes":

Economic valuation is so revealing precisely because it is so much more than a process of monetary commensuration: it is, much more powerfully, a process of 'definition' or social construction in a substantive sense (Smith 2007) which incorporates all kinds of assumptions about social order and socially constructed imaginaries about worth. Economic valuation, in other words, does not stand outside of society: it incorporates in its very making evaluative frames and judgments that can all be traced back to specific politico-institutional configurations and conflicts. (Fourcade 2011, 1769)

Karpik $(2010,36)$ speaks of the valuation of "singularities," nonstandardized goods and services, and suggests that the valuation of singularities is based on "knowledge" and "judgment" rather than "information" and "decision": "Judgment is . . . primarily a qualitative choice, whereas decision is based on logic and calculation," proposes Karpik (2010, 41). As a consequence, certain markets trading singularities such as in the modern art, judgment and knowledge are operationalized as expertise (Gourevitch 2011; Velthuis 2011; 2003). Such expertise is acquired through years of training and experience but is ultimately granted when one is recognized by other actors in one's field. As Luhmann (2000), for instance, has argued, the art market is to some extent autopoetic, self-referential; only experts already recognized by the social system of the art market can recognize the work of newcomers. "The assessment of the value of a work of art is only based on the reputation of the expert, verified by the reputation of others," writes Gourevitch $(2011,88)$.

Muniesa, Millo, and Callon (2007) introduce the term "market devices" in order to denote the totality of instruments, technologies, standards, and infrastructures that constitute the market (see, for example, Preda 2006; Buenza and Stark 2004). More specifically, Karpik (2011) speaks of the use of "judgment devices" that help an actor determine the value of a resource. As "guides for action," judgment devices help the actor to overcome "radical uncertainty" and to "instill confidence" (Karpik 2011, 71). Judgment devices consist of heterogeneous resources that include expert guides and reviews, statements by rating agencies, and professional rules of thumb (e.g., 
“don't buy stocks with a price/earnings ratio over 15 " in financial trading). For instance, in the modern art market, previous art prices, the credentials of the artist (including what galleries or art museums have displayed his/her work), and expert reviews may all serve as judgment devices for the buyer of modern art. The greater the uncertainty involved in making the valuation, the greater the need for widely-used and credible judgment devices: "Judgment devices are used to dissipate the opacity of the market," Karpik summarizes (2010, 44).

In addition to determining the value and, eventually, the price of a resource, agents need to be able to commensurate resources, to compare and rank them in order to be able to make a selection. Valuation and commensuration are two complementary processes not fully separated in time and space; however, for analytical reasons, they can be kept apart.

\section{Commensuration}

In many cases, economic valuation is not the goal per se, rather the determining of economic value is used in commensuration, the translation of different qualities into a common metric (Espeland and Stevens 1998, 314) that can support, for instance, decision-making. In health care organizations, the economic valuation of, for instance, human organs (say, a kidney or a retina) can help to decide what form of surgery to conduct and what priorities to make (Sharp 2003; Cherry 2005). "Commensuration can be understood as a system for discarding information and organizing what remains into new forms. In abstracting and reducing information, the link between what is represented and the empirical world is obscured and uncertainty is absorbed," Espeland and Stevens write (1998, 317). As a consequence, commensuration is a process whereby objects must be classified in ways that "make them comparable"_-liquid," in Carruthers and Stinchcombe's (1999) terms-and it thus requires "considerable social and intellectual investments" (Espeland and Stevens 2008, 408). Commensuration is thus the process whereby heterogeneous resources or assets (e.g., products or services) are given economic values which are to be compared regardless of their differences, or, using Wilson's $(2001,1)$ case: "how many light bulbs should be proffered for a ton of coal?" As Espeland and Stevens $(2008,432)$ remark, commensuration is a form of quantification whereby all resources are subject to economic valuation and, consequently, the risk always exists that "the real easily becomes coextensive with what is measureable." Since the publication of Simmel's (1978) Philosophy of Money, which speaks of money-worth as the ultimate "measure of value" (Wilson 2000,1) in modern society, social theorists have paid attention to how monetary terms serve to commensurate heterogeneous resources (e.g., Baker and Jimerson 1992; Crump 1992). “A market price appears more 
'objective' than other measures of value," Carruthers emphasizes (2005, 358). However, Carruthers suggests, such images of "objectivity" are often a chimera:

The connection between monetary valuation and quantitative measurement gives the former an image of an objective, neutral, and precise mode of valuation .... Ideally, valuation resembles . . . disinterested mechanical objectivity . . . but in fact the rules are often too vague, incomplete, and numerous to prevent interestdriven creative interpretations. (Carruthers 2005, 359)

In order to serve their social role, "economic numbers" (i.e., the monetary worth of a resource) need to comply with at least one of four conditions outlined by Espeland and Stevens (2008, 417):

The authority of numbers may be vested in (1) our sense of their accuracy or validity as representations of some part of the world ... (2) in their usefulness in solving problems .... (3) in how they accumulate and link users who have investments in the numbers ... or (4) in their long and evolving associations with rationality and objectivity ... It often is some combination of these phenomenon that makes particular numbers compelling. (Espeland and Stevens 2008, 417)

While the paradox of economic valuation and commensuration lies in economic numbers, on the one hand, being respected and serving the role of inscribing a resource with economic worth, the uses and interpretations of the same numbers are, of necessity, embedded in social and cultural beliefs (Mackenzie 2004). Economic numbers thus have to be examined as such and need to be understood as representing underlying "non-economic" conditions (Zaloom 2003, 258).

Studies of processes of valuation and commensuration suggest that there is a need for joint agreement regarding classifications and routines for determining economic worth. Studies of the uses of classification in, for example, the film industry (Waguespack and Sorenson 2011) and the finance industry (Fleischer 2009; Mizruchi and Stearns 2001; Zuckerman 1999; Hayward and Boeker 1998) suggest that powerful actors may influence classification work in ways that benefit their interests. In the case of the film industry, independent film producers have received less favorable ratings for their movies and in the case of the finance industry, rating agencies use "overlapping categories" that help to support future claims regarding the accuracy of classifications (e.g., high, moderate and low risk) of financial assets. These studies suggest that valuation and commensuration are not separated from politics and power; on the contrary, being processes that commonly take on objectivist images while reflecting certain interests and accommodating sources of uncertainty. Prices, the outcome of processes of valuation and commensuration, are thus socially-embedded, suggests Velthuis (2011): 
Prices ... are not established by means of neutral market devices that economic agents select in order to serve their own interests, or which emerge because of their efficiency in equilibrating markets, as neoclassical economists have either implicitly or explicitly assumed. Prices are themselves embedded in the meaning structures of markets, in the preexisting institutional framework of these markets, and in the shared values of the agents who populate these markets. (Velthuis 2011, 178)

In other words, status plays a key role in valuation and commensuration (Benjamin and Podolny 1999; Rao 1994; Podolny 1993). "The greater one's status, the more profitable it is to produce a good of a given quality," Podolny writes (1993). Here, Podolny is speaking of a "Matthew effect" (after Merton 1973) on markets, i.e. the effect whereby already prestigious and powerful actors are capable of maintaining their position by exploiting first-mover advantages. In the case of cultural institutions, status is undoubtedly a major factor to consider.

In summary, economic and social life are based on the capacity of actors to value and commensurate heterogeneous resources. In some cases, certain resources (e.g., the price of gold) have been subject to such processes for centuries while in other cases (e.g., natural resources such as "clean air" or human organs used in transplant surgery), such work is largely still in the making. As suggested by economic sociologists, the work of transforming resources into commodities is embedded in calculative procedures as well as in social and cultural norms and beliefs. Thus, the price of a commodity not only reflects its strict economic worth but also the social norms regulating the production of such resources. For instance, the price of sperm, used in reproductive medicine research and in clinical practice for assisted fertilization (Almeling 2007; Tober 2001), not only reflects the supply and demand situation of such human reproductive material, but also embodies the "social" and "emotional" costs to the donor for participating in this specific form of "clinical labour" (Waldby and Cooper 2007, 59). Seen in this way, valuation and commensuration constitute a professional domain of expertise wherein calculative practices and wider social, cultural, and political concerns are taken into account.

\section{The Methodology of the Study}

\section{Research Setting}

The Västra Götaland region of Western Sweden has 1.7 million inhabitants spread over forty-eight municipalities and Sweden's largest culture budget, both in nominal and per capita terms. In Sweden's tradition of culture politics, cultural institutions and culture itself are partly financed by the state (primarily in the case of major cultural institutions); however, it is primarily the regions, the regional 
parliaments, and the individual municipalities that finance culture production. The Swedish regions can decide for themselves how they want to allocate their culture budgets and, in the Västra Götaland region, a Culture Agency was set up in 2000 when four smaller regions merged into the Västra Götaland region during a reform aimed at creating larger administrative units. For actors in culture, there are three sources of public funding: the government, the regional parliaments, and the municipalities. However, in practice, it is mostly regional and municipal funding that is targeted. Swedish culture politics are often described as a political field characterized by shared political interests across party lines with few controversies. In this domain, the Culture Agency officers who were interviewed played the role of bureaucrats allocating culture budgets and monitoring the actual usage of financial resources; a role demanding both political skills and the capacity to value and commensurate culture production.

The Swedish regional culture agencies are of interest to valuation and commensuration studies, economic sociology, and other economic disciplines because they (1) represent a non-market based, bureaucratic-political budgeting process whereby various culture activities are assessed in terms of their social, cultural, and economic value, that is, there are no widely agreed upon methodologies regarding how to make these assessments, implying that there is a significant degree of professional expertise and tacit knowledge involved in reconciling all the various interests and expectations at play in the cultural sector, and because they (2) value and commensurate culture production, a field of production which, in most developed countries, is treated by decision-making bodies as being subject to market failure, that is, market actors tend to undervalue culture production as it fails to effectively price the intrinsic and wider socio-economic value of such culture production. In practice, such perceived market failures lead to a situation whereby culture production is subsidized and publicly-funded. In other words, culture agencies play an active role as market makers, creating opportunities for a lively and dynamic cultural scene by allocating tax revenues to culture production.

\section{Research Design}

Processes of valuation (and, in the case of markets, price-setting) can be studied empirically in a variety of settings. For instance, in markets with "posted," fixed prices (Velthuis 2011) or in spot-markets where prices serve as a "market device" for closing deals (Çaliskan 2007); in legal processes whereby the worth of, for example, human life (Zelizer 1985) or natural resources (Fourcade 2011) are determined; in bureaucratic-political budgeting processes whereby negotiation and political considerations play an important role. In addition, there are also processes of valuation within professional communities, for 
instance, when academic researchers assess research proposals submitted to research funds (Lamont 2009). In the bureaucraticpolitical valuation, the judgment of the actors is embedded in what Fourcade (2011) speaks of as "politico-institutional configurations and conflicts," that is, valuation and commensuration are based on political agendas and agreements.

The present study is based on a case study methodology (Eisenhardt and Graebner 2007; David 2006; Gillham 2000). Case study research is commonly prescribed in cases where there is a lack of research or where it is complicated to formulate precise research questions. Such a framework suggests that it is a shortage of adequate theories that justifies case study methodology. An alternative perspective is that case study methodology provides in-depth insight into the everyday life and work of actors and that detailed accounts of day-to-day practices provided in, for example, interviews provide more details than, for instance, survey methodologies primarily examining opinions and practices in broader populations or groups of actors (Gephart 2004). The present study seeks to explore how cultural endeavors and competence are evaluated and priced in a political and economic context, i.e. that of the regional economy. A qualitative methodology such as a case study methodology is justified on the basis of the intricate balancing of economic, social and politico-cultural considerations managed by the officers of the Regional Culture Office. In addition, case study methodologies have been used by previous research into the valuation of resources (see, for example, Fourcade 2011; Velthuis 2003; Zelizer 1985).

\section{Data Collection}

The data collection process included three sources of empirical material. First, the study is based on interviews with officers of the Culture Agency. At an early stage of the process, the researcher was invited to the Culture Agency to present the research project and its objectives during a weekly start-up meeting held on a Monday morning. The Culture Agency has 20 co-workers, including the Managing Director, the administrative staff, and the officers, of whom nine have so-called specific domains of expertise and responsibility. In the present study, eight of these officers (one was not available at the time of the study) and the Managing Director were interviewed. This is a small sample of interviewees and includes only interlocutors from the Culture Agency. In addition to the Culture Agency officers, representatives of the contracted cultural institutions or members of the Regional Parliament could have been included in the sample in order to bring a wider perspective on the allocation of financial resources. However, as the present study examines the actual process of conducting the valuation and commensuration of the available culture activities, this sample included the relevant actors. An extended 
sample of interviewees would arguably have shed some light on further concerns pertaining to the allocation of budget resources but these interviewees might not have added any substantial insights into the actual bureaucratic-political budgeting processes as such. Therefore, the sample, albeit of limited extent, has validity since all but one of the officers working with the allocation of culture budgets are included in the study.

All the interviews were conducted at the Culture Agency's head office in Gothenburg, Sweden, and lasted for about one hour. The interviews were based on a semi-structured interview guide, taperecorded, and then transcribed verbatim by a senior researcher. Second, the study included the use of internal documents provided by the Culture Agency. These documents included policy documents and documents prescribing the negotiated goals and objectives for the coming period, known as the assignment. The assignment is based on the needs, demands, and aspirations of the focal cultural institution or actor, as well as the culture policies enacted by the regional parliament of the Västra Götaland region. The assignment is thus a form of "hybrid object" wherein cultural, political, and economic objectives are included and balanced. In addition to these goals and objectives, the assignment includes more specified goals accompanied by so-called "indicators" that enable evaluation if the cultural institutions or actors have been able to meet their goals during the period. Thirdly and finally, Internet websites were used which report on regional policies and political objectives, and the role of the Culture Agency. Under the Swedish political system, all political decisions are in the public domain; consequently, political decisions regarding cultural policies are posted on the respective region's website. This Internet-based service provides research work with valuable information.

\section{Data Analysis}

The Internet website was used to collect basic information about the role of the Culture Agency. The internal documents specifying the assignments were examined as a kind of combination of policy documents and contracts; on the one hand, articulating the objectives of the cultural institutions while on the other, making reference to the general political objectives and long-term goals of the Regional Parliament. The interviews were transcribed and different passages of the transcript were given codes. These codes were drawn both from the theoretical framework and from the vocabulary used by the officers. At times, the etic (the outsider's analytical categories) and emic (the insider's practical categories, see Boje 2001) categories were the same. Interview excerpts from different interviews with the same code were located in a new document under a shared heading. The different categories of quotes were finally organized into a sequence enabling the emplotment of the empirical material. 


\section{Valuing and Pricing Culture}

In this section, the empirical material will be examined as constituted by two basic procedures of valuation and commensuration. The formal procedure prescribes that the valuation and commensuration of the cultural institutions' activities and performance should be kept apart; however, in practice, the Culture Agency officers are aware of the status of certain cultural institutions-partly due to their historical "track record," and partly due to their legitimacy in the political system-making commensuration something which is always implicitly present during the valuation process. The ability to analytically and practically separate valuation and commensuration is one of the key professional skills of the Culture Agency officers.

\section{Valuation}

In their professional work, the officers of the Culture Agency make use of two judgment devices: i.e. the so-called assignment, written together with the cultural institutions specifying what activities and objectives institutions should work with during the upcoming three-year period, and the indicators, the parameters for measuring the degree of goal fulfillment. The assignment and the indicators are part of the formal contract that the Culture Agency co-signs with institutions that have long-term financing agreements with the Regional Parliament. One of the officers explained the general design of the assignment, emphasizing that it prescribes both general and specific objectives and conditions:

Certain descriptions are the same for all assignments. In all the assignments, there is this section 'general conditions,' which includes the vision and the Regional Parliament's prioritized goals and which everyone needs to relate to. In addition, the Culture Committee [a political body] has decided that all the assignments need to include goals and indicators in order to increase equality and diversity, as well as accessibility to all disabled persons. That, too, is general. Besides that, there is quite a lot of variation, depending on the activities. (Officer 3)

Generally speaking, the larger the institution and the financing, the more specific the assignments. Still, many of the goals for developing artistic work over the coming years were quite general, e.g. "to contribute to the artistic development of the field' (Officer 3, the Culture Agency). This use of relatively vague formulations testifies to the delicate balancing of political objectives and artistic freedom. Production of the arts must never become politicized; however, at the same time, public funding of the arts has called for some monitoring of activities. Culture Agency officers thus play a subtle role in navigating between acting as a support function for culture and acting as a political body regulating it. One officer addressed this role of the agency thus: 
It is always complicated to be stuck between the political system, which wants to accomplish something, and the [cultural] activities, which also want to accomplish something, so it's a balancing act. You need to understand the activities, their problems and challenges, while also recognizing the political system. (Officer 6)

Practically speaking, the principal approach to handling assignments was to engage in dialogs with representatives of the cultural institutions and to jointly define adequate objectives with the institutions:

The principle behind writing an assignment [document] is to have a conversation with the actors and their board of directors .... That happens on the officers' level. We're supposed to think in terms of 'what's happened during these last three years?' and, based on that, you formulate something. (Officer 4)

Valuation work included the use of indicators specifying what quantitative and qualitative information needed to be collected and reported to the financiers, the Regional Parliament. Defining adequate, relevant, and easy-to-measure indicators of the quality of the underlying cultural production was a source of constant debate and controversy at the Culture Agency. While some of the officers thought it would be of interest to develop more sophisticated metrics for evaluating culture, they also thought such a project would be beset by conflict, both due to such metrics demanding a significant level of expertise and an understanding of culture production and on the basis of professional ideologies regarding culture-in contrast to other forms of production-as having "intrinsic values." One of the officers said:

It would be very interesting to do [more advanced statistical analyses] in culture, but I think that will never be done . . . I think there's a general reluctance to measure ... [ [culture] is supposed to have a substantial 'intrinsic value.' (Officer 3)

Interestingly, in a period characterized by a mania for measuring everything quantitatively, the politicians-the officers frequently used the short-hand term "the political system"-were reluctant to make use of too many of these quantitative performance metrics: "The political system keeps that at arm's length: 'You're supposed to develop the culture sector, not evaluate it!' [say politicians]" (Officer 7). Just as with formulating the assignments, the officers had some leeway regarding how they selected the indicators. One of the officers said that ecological field research could serve as a role model in terms of identifying adequate measures that capture some of the qualities of the entire social system: 
I try to use indicators that are based on what they're counting anyway: How many visitors are there? Are they young? I want to identify smart indicators like when the biologists count a certain beetle, saying something about the entire system .... There are so many poor indicators. (Officer 8)

While the officers were able to elaborate on what indicators to make use of, the political system actually does prescribe certain political objectives for the upcoming three-year period. For instance, diversity issues and the participation of different social strata (e.g., the working class) in culture production and consumption were two political goals set by the Regional Parliament. One of the officers, with the responsibility for dance and stage art, addressed how two of the performing arts schools were assessed in terms of their ability to broaden their recruitment basis:

In cases like these, we look at the recruitment basis and discuss things like: Who gets accepted? How do you find your students? How do you market yourself? On these programs, it's clear that the youngsters are recruited from middle-class strata. When taking a diversity perspective, the recruitment basis is slightly narrow. So we talk quite a bit about that ... how to have a broader recruitment basis. (Officer 2)

At the time of the interviews, in the fall of 2011, the three-year assignments for the 2009-2011 period were being assessed and the new assignments for the 2012-2014 period were being designed at the agency. Just as with the design of the assignments, the assessment of the work done over the last three years balanced the artistic ambitions of the institutions and the political objectives. That is, there were relatively few hard-end data points being reported and assessed, but more qualitative evaluations were being made. "We conduct this review, asking things like 'What does it looks like?' 'How did things turn out?' 'Do the indicators work as intended?' 'Is there anything that needs to be corrected?' We have those kinds of discussions," said Officer 6. Officer 8 added: "It's hard to do reasonable evaluations. And this is where the indicators come in. Unless you measure with a yardstick, how do you measure? That's difficult!" "Making the assessment is always complicated: We need to see how much resources they deal with; how much [money] did they get from us? How many people are involved? You need to have reasonable expectations," argued Officer 4. Goal fulfillment is thus a matter of qualitative evaluation (e.g., did the Opera House get good reviews in the local and national press during the year?), of quantitative measures (e.g., have numbers of paying visitors increased since last year, or over the period?), and of the amount of funding from the region. This assessment was a domain of professional expertise and political savoirfaire that demanded experience and an understanding of both culture and the political system. In cases where the cultural institution, or the actor, has apparently failed to accomplish what has been promised, the 
officers could advise the Regional Parliament to cut down on, or even withdraw, funding. However, such a scenario was a failure for all parties and the officers regarded it as the last resort:

\footnotetext{
We need to be very well informed before saying to the political system: 'based on my assessment, I propose that you cut the budget for this activity by this much' ... I have a great deal of responsibility when making my assessment. It is not simply a matter of saying 'they need more money.' I have just as much responsibility to ensure that these activities use their money in the best way, that they do what is expected of them, and that tax revenues are not squandered. If that is the case, then I tell them: 'I don't think this is what we asked you to do.' (Officer 4)
}

Taken together, the valuation of culture production was organized as a professional domain of expertise wherein the judgment devices of the assignment and the indicators were defined on the basis of both the demands and the needs of the cultural institutions and actors, and the need for political oversight and control. While the assignments were formally regarded as contracts between the Regional Parliament and the cultural institutions and actors, based on the possibility of assessing goal fulfillment on the basis of quantitative and qualitative indicators, there were, in practice, ongoing discussions and exchanges of information between the Culture Agency officers and the cultural institutions and actors. The valuation of cultural endeavors was thus embedded in social relations and political traditions. At times, the officers stressed the difficulties of reforming a system with its roots in the eighteenth century, when the culture sector was financed by the state and the wealthy bourgeoisie. Path-dependencies and history matter, and it was only slowly that culture could be transformed into a more socially-relevant and economically value-adding activity capable of carrying its own costs. At the same time, the officers saw their own role in terms of being "administrators in the service of democracy," stressing the need to enact a wide and comprehensive image of culture, not only in the form of high-brow elite culture and stage-art but also as something that includes public education and various forms of folklore art. The specific and general assignments of three major culture institutions are summarized in Tables 1 and 2 below. 


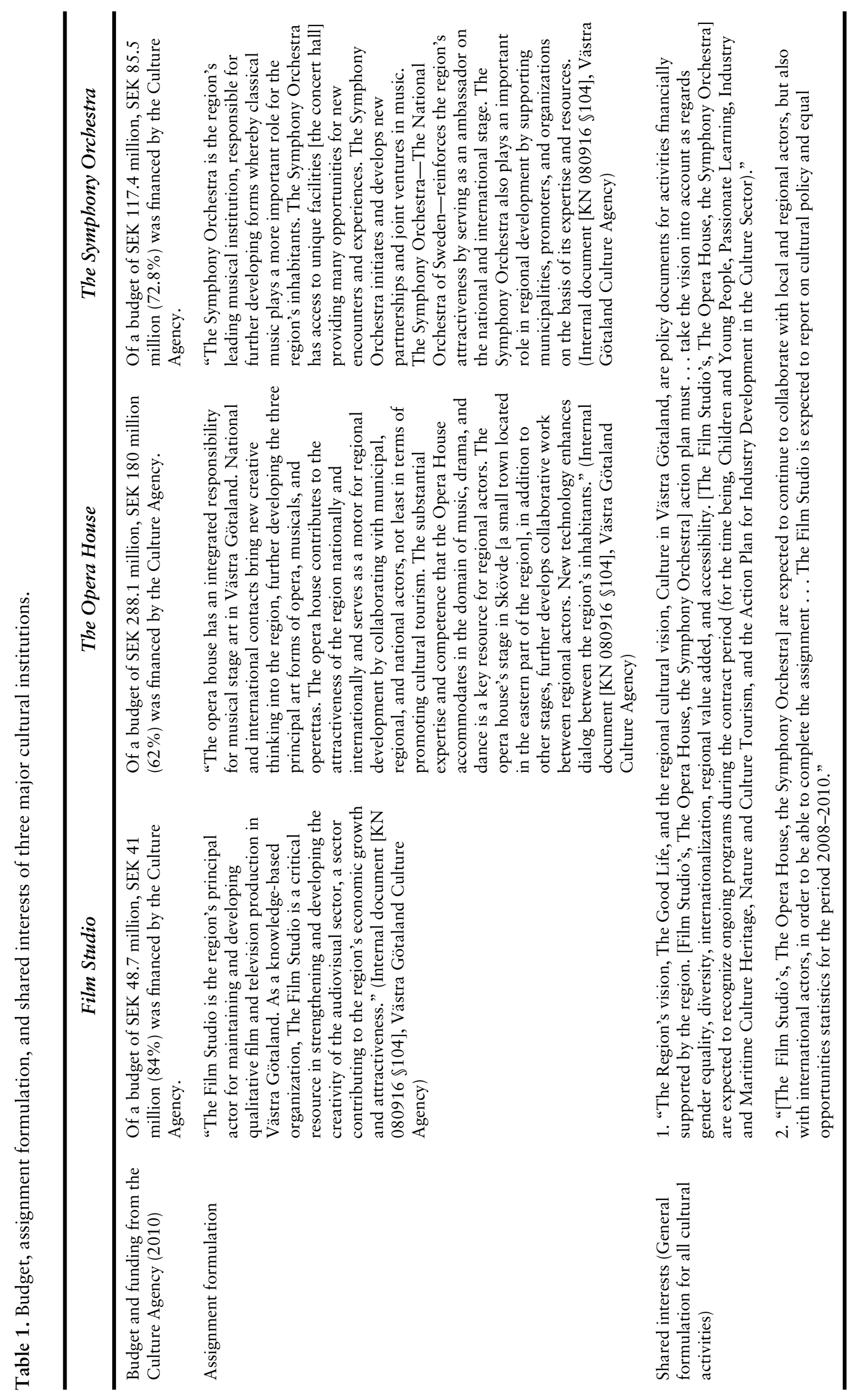




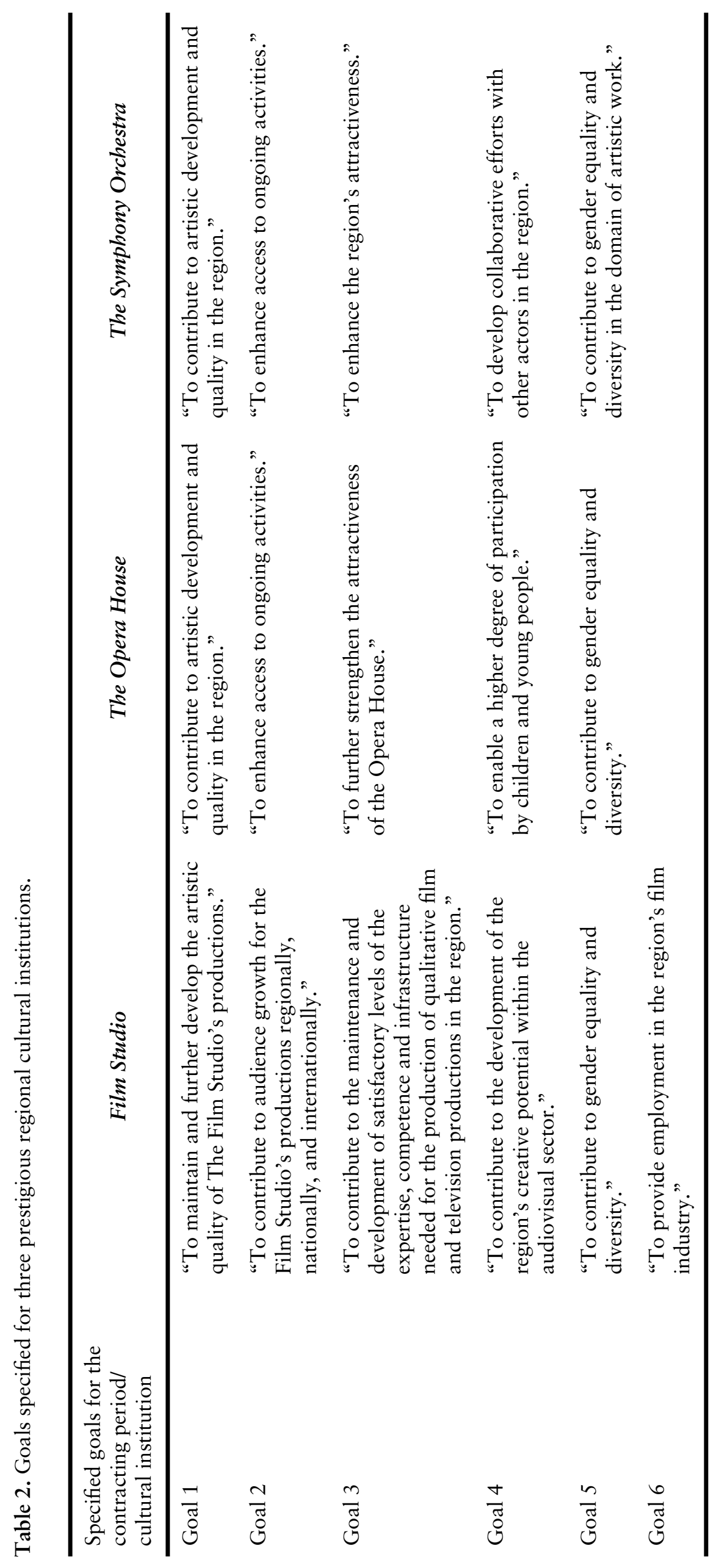




\section{Commensuration}

The entire culture budget of the region included three basic forms of culture funding: (1) Regular long-term contracts with major institutions; (2) Short-term project funding for new and innovative culture activities; (3) "Strategic culture projects" aimed at creating new "infrastructures" in culture or connecting culture with, for example, industry or education. The first category of funding consumed the largest share of the budget while the second category was dependent on the quality of incoming applications during the year. Around three hundred short-term project applications were reviewed annually, with roughly eighty receiving money from the budget of seventeen million Swedish crowns. The third category of funding included a variety of projects that the Culture Agency initiated in order to further strengthen culture and its connections with other domains of society. When allocating financial resources to different activities, officers needed to be able to compare and commensurate these activities. While much of the allocating was expected to continue as previouslythe major cultural institutions expected to receive their share of the pie; there was no political agenda to shift the focus-for example, project applications were competing over limited resources. Officers made reference to at least three objectives when making their assessments: (1) the democratic objectives enacted by the political system; (2) the contribution to economic growth; and-more controversially and not fully recognized-(3) the status of the cultural institution or actor. Perhaps counter-intuitively, artistic quality was not one of the principal assessment criteria as the officers regarded that as lying outside their domain of jurisdiction.

In terms of democratic objectives, all the cultural institutions and actors receiving regional funding needed to demonstrate at least a minimum amount of understanding of their regional role and their connections with their socio-economic and cultural settings:

If you're a regional company, you'll be socialized into the regional role. They can identify everything that the Västra Götaland region stands for, so that isn't a problem .... If you receive seventy million crowns annually from the region, you'll need to be able to say something about what the Västra Götaland region is all about! (Officer 7)

For more small-scale projects, such "political awareness" was not expected, but the officers required each project funded to be "regionally relevant," that is, to comply with the objectives of the Regional Parliament. Officer 7 continued: "If we recommend financial support to eighty projects, then we want all of the political goals to be met across the entire batch, but that doesn't suggest that every [single] project needs to do that." In fact, one of the major reasons for refusing to provide project-funding was the lack of an explanation as to why this particular project would contribute to the development of the 
region-culturally, socially, or economically. One of the consequences of the emphasis on regional relevance was the officers needing to keep the actors in the field at arm's length: "We mustn't become buddies with people. I have been reluctant to that. For a long period of time, I was yelled at [for proposing the withdrawal of funding for an institution] ... . You need to be able to live with that" (Officer 8); "There are some people who think I'm an idiot but they're very much the exception," she contended. According to the officers at the Culture Agency, the regional administration could make a substantial contribution to culture because of the vital combination of local knowhow and the capacity to oversee territories larger than the individual municipality: "After all, the regional level is the ultimate level for dialog with the citizenry: the state is too far away, the municipalities are myopic ... [the region] has know-how regarding local conditions but it still has some oversight," claimed Officer 7. In Sweden's new national cultural policy, the regions also receive a stronger role as they are given the responsibility of also allocating national funding of culture, further emphasizing the focus on regional relevance.

Secondly, the relationship between regional economic growth and culture was emphasized in the commensuration of culture resources. While culture has, in many quarters, been treated as a sacred, highbrow activity to be carefully separated from everyday life, it is increasingly being connected with the question of economic growth and the role of creativity and aesthetic knowledge during the contemporary period. Officer 2 stressed this view of culture:

We [the Culture Agency] are part of an economic growth organization . . . A growth-based cultural activity needs to have the incentives to endorse some kind of industry perspective. It's really a bit of a challenge to encourage such a view . . . . I think I'm doing my best to bring that perspective into discussions with the major institutions. (Officer 2)

According to Officer 2, representatives of culture are much more receptive today to the concept of enacting a broader view of culture: "[in 1990s] things became really infected when you talked about the 'intangible value of culture.' It was like swearing in church" (Officer 2). Today, culture actors are, claimed the officers, less inclined to get on their high horse. Also, the political system seems to be more attracted to the notion of a creative economy driven by artistic and aesthetic know-how:

I think our Regional Parliament has been thinking quite a lot in such terms and at times, we've even been accused of taking an 'instrumental view.' I don't see anything wrong with that .... If there's no money available in society, then there won't be any resources available for culture-at least not publically-funded culture ... I'm not one of those who think that culture has an 'intrinsic value'. (Officer 4) 
Officer 4 continued:

Culture cannot exist in isolation, it needs to be a co-producer of society in a much more visible manner. Those working with culture view themselves with pride because they have competence, something to contribute, and they don't need to be too concerned if they paint one day and inspire a group of school children the next. (Officer 4)

Tourism and the entrepreneurial spirit, nourished in the art schools financed by the Regional Parliament, were two examples of economic growth deriving from culture. "The art schools, for instance," said Officer 3, "create entrepreneurs ... they [the students] learn to think outside the little box constituting most people's thinking." "Tourism is one of the activities that extracts value from the [cultural] institutions .... it's like an indicator per se of what is relevant and what has worth," said Officer 5. Some of the officers made reference to a recent study suggesting that each Swedish crown invested in culture brings three and a half in return; consequently, some of the officers spoke of the financing of culture not so much in terms of "public funding" but in terms of "socio-economic investment." Some of the officers expressed rather extensive lines of reasoning as regards what their regional role and assignment were, stressing that economic growth is the ultimate goal of their activities: "We organize the production of natural resources, we are at the core of the cultural and creative industries. . . Unless there is some production of natural resources, there will be nothing to refine further," said Officer 8 . She continued: "Those at the core . . . organizations and so forth, unless they understand that they need to be at least slightly concerned with [adding value to the economy], they will be mistaken! It's our duty to be at least reasonably informed and to try and maintain a dialog [regarding such matters]." One of the officers argued that there was a lack of adequate vocabulary to address the economic potential of culture. The entire discourse regarding the role of culture in society is stuck in manufacturing vocabulary, emphasizing terms such as production and consumption, and with clearly-bounded and separated organizations serving their specialized roles. Today, he argued, culture is being valued on the basis of narrow and instrumental, and at times even techno-scientific, evaluations:

It's a matter of defining values. It's a matter of defining values different to measuring the transmitter substances emitted when someone plays Mozart, or how many people passed a turnstile . . . Based on such discussions, you build a new set of activities and products that were previously undefined. At that point, you may be able to have a reasonable conversation ... To date, such scenarios and activities remain unarticulated. (Officer 5)

For instance, evaluating the success of a cultural institution by "looking at how many pass the turnstiles" already assumes that 
culture is located in specific sites, particular buildings wherein culture is both produced and consumed, argued Officer 5. In the future, a more subtle and evocative vocabulary and analytical framework will be needed to be able to fulfill the economic potential of cultural competence. For most of the Culture Agency officers, national cultural policy, developed in Stockholm, was too bound up with such antiquated ideas about culture, rendering national cultural policy basically irrelevant. Speaking of the difference between "art policies," defined as the "high-brow professional art" produced by institutions and advocated, for example, by the Swedish Arts Council (Kulturradet), and "cultural policies" as a wider and more sociallyrelevant political agenda, including both the arts and other forms of culture and public education supported by the Culture Agency, national cultural policy was side-lined through being outmoded and introverted: "I've never ever heard the Arts Council speaking about the creative industries, or actually showing any interest in them .... That's important to us, but not to the Arts Council," said Officer 7. Trying to think of culture in new and innovative terms, as well as trying to connect issues of economic growth, demands new vocabularies and a new analytical framework, but these were not to be found in national cultural policies.

Regardless of ambitions to institute new perspectives on culture, a third aspect of the commensuration of culture resources pertains to the question of status. The largest share of the culture budget was allocated to the major institutions, e.g. the symphony orchestra, the Opera House, a number of theatre companies, and a film studio. Of a budget of SEK 905 million (2011), only SEK 17 million was allocated to new culture projects. This emphasis on supporting the major cultural institutions enjoyed strong political support in the Regional Parliament, but many of the officers of the Culture Agency expressed their concerns regarding the distribution of tax revenues. Said one of the officers:

When I started here, I was fascinated by the Opera House, for instance. They receive an incredible amount of money ... [the Opera house] is primarily patronized by the grey-haired middle-class. They get these amounts of financial resources because it's been decided that their social worth is so high, a high social value ... The income [from ticket sales] is in no way on a par with costs ... How should we evaluate culture within political systems? (Officer 3)

Many of the officers made reference to a recent study suggesting that around 95 percent of the population never visited the major cultural institutions, pointing to the relatively weak correlation between the use of tax revenues and the actual benefit to the tax payer. One of the officers claimed, in a rather straightforward manner, that all the talk about the "creative economy" and so forth, emphasizing the economic consequences of the creative industries, was only a form of rhetoric 
thinly veiling the fact that most major institutions were primarily concerned about doing what they have always done-producing performing arts:

People say one thing but want something else ... I believe people think economic growth is the same as prostituting yourself. The culture sector is 'way too sophisticated' to participate in discussions like that. Its 'higher value' is so comprehensive and sacred that it 'evades all such measurement' ... You mustn't get your hands dirty dealing with money: at best, they can accept sponsoring. (Officer 5)

In general, the higher the status of the cultural institution-especially if it had acquired international status-the more complicated it would be to deal with, the officers argued; "The bigger the dragon, the harder to handle, no doubt about it!", Officer 7 exclaimed. Functionally speaking, status and prestige are past accomplishments translated into credibility, a stock of social capital that is also translated into an inflow of economic capital. While the officers were highly aware of both the path-dependencies and the lock-in effects deriving from the influence of status, claiming that the political system tended to overlook the fact that only a smallish proportion of the voters actually took advantage of the major cultural institutions, they had few possibilities of re-allocating economic resources. Status thus served to cement culture into a few large-scale activities, with many small projects and activities.

In summary, the valuation and commensuration of cultural resources is organized in practical terms into two individual sets of activities. Valuation is based on the use of judgment devices such as the assignment and use of indicators that help Culture Agency officers to create an agreement between the political system, which they serve, and the actors working in culture. The commensuration of cultural resources was based on an analysis of the culture activity's ability to comply with the long-term objectives of the political system and the contribution made to economic growth. In addition, status played a role as to what from the outset determined where the economic resources would be allocated. While valuation and commensuration are not fully separated in time and space, there were mechanisms and tools, such as the assignments and indicators, that emphasized the distinction between the two processes. Valuation served to determine the social and economic benefits of a cultural resource, examining the value per se, while commensuration served to rank the various cultural resources in order to be able to draw a line of demarcation between cultural resources financed by tax revenues and those that were not. 


\section{Discussion}

Sweden's culture policy has for decades been emphasizing culture as a benefit to the public; consequently, it has primarily been financed by tax revenues. As culture budgets are limited, there is a need for mechanisms and procedures that both warrant the long-term stability of major cultural institutions and encourage the development of new and creative activities. Studying the work of the officers of the Culture Agency reveals that processes of valuation and commensuration in bureaucratic-political budgeting processes-central to the transparent and efficient allocation of tax revenues-occur at the intersection between the political system (i.e. the Regional Parliament and its Culture Committee) and the largely heterogeneous cultural sphere. While the officers regard themselves primarily as servants of the political systems and the citizens of the region, they have a significant degree of professional autonomy in how they monitor and oversee how tax revenues are translated into actual culture production. As suggested by Fourcade (2011, 1769), economic valuation "does not stand outside of society;" rather, "evaluative frames and judgments" are embedded in various social, historical, and cultural conditions. More specifically, in the case of the Culture Agency, what Fourcade (2011, 1769) refers to as the "specific politico-institutional configurations and conflicts" play a key role in shaping how budgets are allocated. Major cultural institutions and representatives of the political system are in many ways in direct communication, thus sidelining the Culture Agency officers and negotiating a shared view of how the culture budget should be allocated. At the same time, what Beckert (2009) speaks of as the "value problem," e.g., how cultural resources are inscribed with an economic value, demands specific expertise. The officers of the Culture Agency serve a vital role in the specific politico-institutional configuration of Sweden's culture sector. They are, in their own view, the de facto "administrators of democracy" and "the culture bureaucrats"-the term "bureaucrat" here being used in a non-pejorative manner-inasmuch as they make use of judgment devices such as the assignment to value and commensurate cultural activities. The political system itself cannot accommodate such expertise because that would entail a politicization of culture, and the actors of the culture sector are not in any position to fully overview that sector. Only experts with an intimate understanding of the two social systems, the political system and the culture sector, are in a position to make informed judgments based on their entrenched know-how and experience. Similar to the modern art market experts examined by Gourevitch (2011) and Velthuis (2011; 2003), not only passively responding to market requests and changes but also actively creating the modern art market by instituting certain standards and routines enabling the economic valuation of the 
singularity of the modern art object, the officers of the Culture Agency do not merely operate as a neutral and disinterested mechanism in their domain of expertise but instead actively influence both the political system that they serve and the culture sphere that they monitor.

Such an expert role is not, the study shows, devoid of ambiguities and difficulties. For instance, what Espeland and Stevens (2008) speak of as "the authority of numbers" and what Porter (1995) addresses as the "trust in numbers"-and especially numbers in the form of "market prices" (Carruthers 2005)-i.e. the belief in certain quarters that indicators should be able to unproblematically represent underlying activities, resources, or accomplishments, is a source of debate and discussion. For some officers, the lack of reliable and valid indicators is a major concern demanding further attention, while for other officers, the very idea of such metrics derives from images of culture modeled on an industrial production model that is either irrelevant to culture production or more generally outmoded in the emerging creative economy. Many forms of commensuration examined in the literature are based on the joint enactment of relatively stable figures and metrics, e.g., market prices that signal the perceived economic worth of an asset; however, in the case of the Culture Agency officers' commensuration of culture activities, the formal reporting of performance data, e.g., the number of tickets sold and the degree of self-financing, such data played only a supplementary role as long as the performance data was satisfactory. Instead, the commensuration of culture activities was compared on the basis of a variety of considerations deriving from the political decisionmaking procedures that prescribe the role of the regional cultural sector. That is, metrics mattered, but only to the extent that they were used to monitor ongoing activities, rarely being used in separation from other, more qualitative assessments when advising the political system. In comparison to, for example, Espeland and Sauder's (2007) and Sauder and Espeland's (2008) study of the ranking of law schools, or Kornberger and Carter's (2010) study of the uses of league tables when ranking cities, the commensuration conducted by the Culture Agency officers treated quantitative measures not so much as the final and comprehensive output of their analytical work but as its starting point. In the case of ranking-arguably one of the commensuration tools most strongly stressing the discrimination that exists between competing actors-the Culture Agency officers were reluctant to create these kinds of lists and rankings as they would ignore or overlook important differences between different cultural institutions. As the officers frequently pointed out, their assignment, as a politicallyregulated agency, was not to "assess the performance of the cultural institutions" but to "further develop culture." 
The study contributes to the economic sociology literature portraying valuation and commensuration as central economic practices in the contemporary economy (Fourcade 2011; Aspers 2009; Fleischer 2009; Espeland and Stevens 2008; Yakubovich, Granovetter, and McGuire 2005; Zaloom 2003; Zelizer 1985). Many studies of valuation and commensuration have emphasized the constitution of markets and market mechanisms for goods and commodities, e.g. art (Gourevitch 2011; Velthuis 2011; 2003), strawberries (Garcia-Parpet 2007), cotton (Çaliskan 2007), electricity (Yakubovich, Granovetter, and McGuire 2005), but also resources more complicated to value, e.g. labor (Biernacki 1995), natural resources (Fourcade 2011), and "special goods" more generally (Karpik 2010). In contrast, the study reported on in this article examines valuation and commensuration practices in culture production within the politico-institutional framework of Swedish regional culture policies. While there are apparent differences between the trading of strawberries and cotton on a spot-market, and the allocating of tax revenues in a regio-political setting, there are, arguably, shared underlying domains of expertise in these diverse economic practices. All sorts of valuation and commensuration practices make use of judgment devices and other tools and heuristics-e.g., Beunza and Stark (2004) speak of the "instrumentation" of financial traders' work-being mobilized. In addition, all processes of valuation and commensuration are riddled with ambiguities, uncertainty, and political interests, putting pressure on, for example, the Culture Agency officers to develop and make use of assignment documents and indicators providing them with a set of resources designed to help them negotiate with representatives of the cultural institutions.

In summary, the study demonstrates that the skill of valuing and commensurating in the domain of bureaucratic-political resource allocation is based on professional expertise and experience acquired during years of practice at the intersection between the political sphere and the cultural sector, as well as through the application of the routines and standard operation procedures gradually being stabilized in the face of controversies, discussions, and perceived problems. Moreover, the study shifts the focus away from markets and market devices, examining the specific forms of valuation and commensuration, within political systems and public sector activities, which are financed by tax revenues. That is, the study examines how culture is inscribed with social and economic worth in bureaucraticpolitical settings and how a "market for culture" is produced on the basis of such professional activities.

The study has some limitations that need to be addressed. It includes a limited sample of interviewees, but it also includes all but one of the officers monitoring culture production at the Culture Agency. A larger set of interviewees could have been collected from 
other regions, preferably in Sweden's other two metropolitan areas, i.e. Stockholm and Skåne Region. Since the case of the Swedish culture sector is an idiosyncratic one, it would be complicated to speak of the work of the Culture Agency officers in terms of a general case of economic valuation and commensuration. Instead, this specific case, regardless of all regional/national historical and cultural traits, can be regarded as an example of how professional skills and administrative routines, ultimately embedded in democratically-elected political bodies, recursively structure as well as inform processes of valuation and commensuration while simultaneously being constituted by such economic procedures.

\section{Conclusion}

Economic sociology has contributed to liberating the study of economic behavior from one-sided instrumental rationalities such as rational choice theories. Such new theoretical frameworks have paved the way for more situated and localized views of economic action and thick descriptions of how, for instance, economic resources are allocated. The present study of how culture production is valued and commensurated within Swedish culture policy, i.e., in the case of tax revenues allocated to cultural institutions and actors, demonstrates that such processes aim to strike a balance between various interestspolitical, economic, and cultural. In fact, one of the key skills of the Culture Agency officers lies precisely in integrating such heterogeneous concerns into the analysis while keeping them apart, practically and politically (see, for example, Berglund and Werr 2000); the processes of valuing and commensurating culture resources are thus part of a professional domain of expertise in its own right, which helps officers to navigate between the risks of politicizing the culture sector, on the one hand, and establishing too lax and laissez-faire a politico-cultural regime with no functional political oversight, on the other. The study thus contributes to the literature on economic sociology and studies of the practices of valuation and commensuration, procedures that have primarily been examined in market settings, by underlining the fact that such practices also play a key role in both the public sector and in fields where calculative rationalities cannot strictly be applied without violating other professional norms and beliefs.

Acknowledgements. The author would like to thank the Culture Agency officers that participated in the study, and the editors and the anonymous reviewers for their helpful comments on earlier versions of the text. 


\section{References}

Adler, Nancy J. 2011. "Leading Beautifully: The Creative Economy and Beyond." Journal of Management Inquiry 20 (3): 208-221.

Almeling, Renee. 2007. "Selling Genes, Selling Gender: Egg Agencies, Sperm Banks, and the Medical Market in Genetic Material." American Sociological Review 73 (3): 319-340.

Aspers, Patrik. 2009. "Knowledge and Valuation in Markets." Theory and Society 38 (2): 111-131.

Beckert, Jens. 2002. Beyond the Market: The Social Foundation of Economic Efficiency, translated by Barbara Hershaw. Princeton: Princeton University Press.

- 2009. "The Social Order of Markets." Theory and Society 38: 245269.

Beckert, Jens, and Patrik Aspers, eds. 2011. The Worth of Goods: Valuation and Pricing in the Economy. Princeton: Princeton University.

Berglund, Johan, and Andreas Werr. 2000. "The Invincible Character of Management Consulting Rhetoric: How One Blends Incommensurates While Keeping Them Apart." Organization 7 (4): 633-655.

Baker, Wayne, and Jason Jimerson. 1992. "The Sociology of Money." American Behavioral Scientist 35: 678-693.

Benjamin, Beth A., and Joel M. Podolny. 1999. "Status, Quality, and Social Order in the Californian Wine Industry." Administrative Science Quarterly 44 (3): 563-589.

Biernacki, Richard. 1995. The Fabrication of Labor: Germany and Britain, 1640-1914. Berkeley and Los Angeles: University of California Press.

Boje, David M. 2001. Narrative Methods for Organization Research \& Communication Research. London, Thousand Oaks \& New Delhi: Sage.

Bourdieu, Pierre. 2005. The Economic Structures of Society. Cambridge: Polity Press.

Çaliskan, Koray. 2007. "Price as a Market Device: Cotton Trading in the Izmir Mercantile Exchange." Sociological Review 55: 241-260.

Callon, Michel, ed. 1998. Laws of the Market. Oxford: Blackwell.

Carruthers, Bruce G. 2005. "The Sociology of Money and Credit." In The Handbook of Economic Sociology, second ed., edited by Neil J. Smelser and Richard Swedberg, 355-378. Princeton \& London: Princeton University Press.

Carruthers, Bruce G., and Sarah Babb. 1996. "The Color of Money and the Nature of Value: Greenbacks and Gold in Postbellum America." American Journal of Sociology 101 (6): 1556-1591.

Carruthers, Bruce G., and Wendy Nelson Espeland. 1991. ”Accounting for Rationality: Double-Entry Book-Keeping and the Rhetoric of Economic Rationality." American Journal of Sociology 97 (1): 31-69.

Carruthers, Bruce G., and Arthur L. Stinchcombe. 1999. "The Social Structure of Liquidity Flexibility, Markets and States." Theory and Society 28: 353-382. 
Cherry, Mark J. 2005. Kidney For Sale by Owner: Transplantation and the Market. Washington: Georgetown University Press.

Crump, Thomas. 1992. "Money as a Ritual System." American Behavioral Scientist 33: 669-677.

David, Matthew, ed. 2006. Case Study Research Vol. 1. London, Thousand Oaks \& New Delhi: Sage.

DiMaggio, Paul, and Hugh Louch. 1998. "Socially Embedded Consumer Transactions: For What Kinds of Purchases Do People Most Often Use Networks." American Sociological Review 63 (5): 619-637.

Eisenhardt, Kathleen M., and Melissa E. Graebner. 2007. "Theory Building from Cases: Opportunities and Challenges." Academy of Management Journal 50 (1): 25-32.

Ericson, Richard, Dean Barry, and Aaron Doyle. 2000. "The Moral Hazard of Neo-Liberalism: Lessons from the Private Insurance Industry." Economy and Society 29 (4): 532-558.

Espeland, Wendy Nelson, and Michael Sauder. 2007. "Ranking and Reactivity: How Public Measures Recreate Social Worlds." American Journal of Sociology 113 (1): 1-40.

Espeland, Wendy Nelson, and Mitchell L. Stevens. 1998. "Commensuration as a Social Process." Annual Review of Sociology 24: 13-24.

-. 2008. "A Sociology of Quantification." European Journal of Sociology 49 (3): 401-436.

Ewenstein, Boris, and Jennifer Whyte. 2007. "Beyond Words: Aesthetic Knowledge and Knowing in Organizations." Organization Studies 28 (5): 689-708.

Fleischer, Anne. 2009. "Ambiguity and the Equity of Rating Systems: United States Brokerage Firms, 1995-2000.” Administrative Science Quarterly 54 (4): 555-574.

Fligstein, Neil. 2001. The Architecture of Markets. Princeton: Princeton University Press.

Fischer, Jill. 2009. Medical Research for Hire: The Political Economy of Pharmaceutical Clinical Trials. New Brunswick: Rutgers University Press.

Fourcade, Marion. 2011. "Cents and Sensibility: Economic Valuation and the Nature of 'Nature'." American Journal of Sociology 116 (6): 17211777.

Garcia-Parpet, Marie-France. 2007. "The Social Construction of a Perfect Market: The Strawberry Auction at Fontaines-en-Sologne." In Do Economists Make Markets? On the Performativity of Economics, edited by Donald A. Mackenzie, Fabian Muniesa and Lucia Siu, 20-53. Princeton \& Oxford: Princeton University Press.

Gephart, Robert P. Jr. 2004. "From the Editors: Qualitative research and Academy of Management Journal." Academy of Management Journal 47 (4): 454-462.

Gillham, Bill. 2000. Case Study Methods. London \& New York: Continuum. Gourevich, Peter. 2011. "The Value of Ethics: Monitoring Normative Compliance in Ethical Consumption Markets." In The Worth of Goods: 
Valuation and Pricing in the Economy, edited by Jens Beckert and Patrik Aspers, 86-105. Princeton: Princeton University Press.

Guillén, Mauro F., Randall Collins, Paula England, and Marshall Meyer. 2002. "The Revival of Economic Sociology." In The New Economic Sociology: Development in Emerging Fields, edited by Mauro F. Guillén, Randall Collins, Paula England and Marshall Meyer, 1-32. New York: Russell Sage Foundation.

Hayward, Matthew L.A., and Warren Boeker. 1998. "Power and Conflict of Interest in Professional Firms: Evidence from Investment Banking." Administrative Science Quarterly 43: 1-22.

Howkins, John. 2002. The Creative Economy. Harmondsworth: Penguin.

Karpik, Lucien. 2010. Valuing the Unique: The Economics of Singularities. Princeton: Princeton University Press.

- 2011. "What's the Price of a Scientific Paper?" In The Worth of Goods: Valuation and Pricing in the Economy, edited by Jens Beckert and Patrik Aspers, 63-85. Princeton: Princeton University Press.

Kornberger, Martin, and Chris Carter. 2010. "Manufacturing Competition: How Accounting Practices Shape Strategy Making in Cities.” Accounting, Auditing \& Accountability Journal 23 (3): 325-349.

Lamont, Michèle. 2009. How Professors Think: Inside the Curious World of Academic Judgment. Cambridge Mass.: Harvard University Press.

Luhmann, Niklas. 2000. Art as a Social System, translated by Eva M. Knodt. Stanford: Stanford University Press.

Mackenzie, Donald. 2004. "The Big, Bad Wolf and the Rational Market: Portfolio Investment, the 1987 Crash and the Performativity of Economics." Economy and Society 33 (3): 303-334.

- 2009. Material Markets: How Economic Agents Are Constructed. Oxford \& New York: Oxford University Press.

Merton, Robert K. 1973. The Sociology of Science: Theoretical and Empirical Investigations, edited by Norman W. Storer. Chicago: The University of Chicago Press.

Mizruchi, Mark S., and Linda Brewster Stearns. 2001. "Getting Deals Done: The Use of Social Networks in Bank Decision-Making." American Sociological Review 66: 647-671.

Muniesa, Fabian, Yuval Millo, and Michel Callon. 2007. “An Introduction to Market Devices." In Market Devices, edited by Michel Callon, Yuval Millo and Fabian Muniesa, 1-12. Oxford \& Malden: Blackwell.

Petryna, Adriana. 2009. When Experiments Travel: Clinical Trials and the Global Search for Human Subjects. Durham \& London: Duke University Press.

Preda, Alex. 2006. "Socio-Technical Agency in Financial Markets: The Case of the Stock Ticker." Social Studies of Science 36: 753-782.

Podolny, Joel M. 1993. "A Status-Based Model of Market Compensation” American Journal of Sociology 98: 829-872.

Porter, Theodore M. 1995. Trust in Numbers: The Pursuit of Objectivity in Science and Public Life. Princeton: Princeton University Press. 
Poovey, Mary. 1998. The History of the Modern Fact. Chicago \& London: University of Chicago Press.

Rao, Haygreeva. 1994. "The Social Construction of Reputation: Certification Contests, Legitimation, and the Survival of Organizations in the American Automobile Industry 1985-1912." Strategic Management Journal 15: 29-44.

Robson, Keith. 1992. "Accounting Numbers as Inscriptions: Action at Distance and the Development of Accounting." Accounting, Organizations, and Society 17 (7): 685-708.

Samuel. Sajay, Mark W. Dirsmith, and Barbara McElroy. 2005 "Monetized Medicine: From the Physical to the Fiscal." Accounting, Organization and Society 30: 249-278.

Sauder, Michael, and Wendy Nelson Espeland. 2009. "The Discipline of Rankings: Tight Coupling and Organizational Change." American Sociological Review 74: 63-82.

Simmel, George. 1978. The Philosophy of Money. London: Routledge and Kegan Paul.

Sharp, Lesley A. 2003. Strange Harvest: Organ Transplants, Denatured Bodies, and the Transformed Self. Berkeley: University of California Press.

Swedberg, Richard. 2005. "Markets in Sociology." In The Handbook of Economic Sociology, second ed., edited by Neil J. Smelser and Richard Swedberg, 233-253. Princeton \& London: Princeton University Press.

Star, Susan Leigh. 1999. "The Ethnography of Infrastructure." American Behavioral Scientist 43 (3): 377-391.

Tober, Diande M. 2001. "Semen as Gift, Semen as Good: Reproductive Workers and the Market in Altruism." Body \& Society 7 (2-3): 137-160.

Uzzi, Brian. 1999. "Embeddedness in the Making of Financial Capital: How Social Relations and Networks Benefit Firms Seeking Financing." American Sociological Review 64 (4): 481-505.

Uzzi, Brian, and Ryon Lancaster. 2002. "Relational Embeddedness and Learning: The Case of Bank Loan Managers and Their Clients." Management Science 49: 383-399.

Velthuis, Olaf. 2003. "Symbolic Meanings of Prices: Constructing the Value of Contemporary Art in Amsterdam and New York." Theory and Society 32: $181-215$.

—. 2011. "Damien's Dangerous Idea: Valuing Contemporary Art." In The Worth of Goods: Valuation and Pricing in the Economy, edited by Jens Beckert and Patrik Aspers, 178-200. Princeton: Princeton University Press.

Waguespack, David M., and Olav Sorenson. 2011. "The Rating Game: Asymmetry in Classification." Organization Science 22 (3): 541-553.

Waldby, Cathy, and Melinda Cooper. 2007. "The Biopolitics of Reproduction: Post-Fordist Biotechnology and Women's Clinical Labour." Australian Feminist Studies 23: 57-73. 
Wilson, Ted. 2000. Battles for the Standard: Bimetallism and the Spread of the Gold Standard in the Nineteenth Century. Aldershot: Ashgate.

Yakubovich, Valery, Mark Granovetter, and Patrick McGuire. 2005. "Electric Charges: The Social Construction of Rate Systems." Theory and Society 34: 579-612.

Zaloom, Caitlin. 2003. "Ambiguous Numbers: Trading Technologies and Interpretation in Financial Markets." American Ethnologist 30: 258-272.

Zelizer, Viviana. 1985. Pricing the Priceless Child: The Changing Social Value of Children. New York: Basic Books.

- 2005. The Purchase of Intimacy. Princeton: Princeton University Press.

Zuckerman, Ezra W. 1999. "The Categorical Imperative: Securities Analysts and the Illegitimacy Discount." American Journal of Sociology 104: 1398-1438.

Alexander Styhre, Ph.D, is chair of Organization Theory and Management; Dept. of Business Administration; School of Business, Economics and Law; University of Gothenburg. He has published widely in the field of organization theory and his work has appeared in Journal of Management Studies, Organization Studies, Human Relations, Organization, and elsewhere. In addition, he is author and co-editor of several research monographs and textbooks including the most recent Organizations and the Bioeconomy (2012) and Assembling Health Care Organizations (co-authored with Kajsa Lindberg and Lars Walter 2012). Styhre is the editor-in-chief of Scandinavian Journal of Management. 
